\title{
Minutes of the August 2016 APSA Council Meeting
}

\author{
August 31, 2016 Philadelphia, \\ Pennsylvania
}

\begin{abstract}
PRESENT
President:Jennifer Hochschild; President-Elect: David Lake; Vice Presidents: Frank Baumgartner and Martha Finnemore; Treasurer: Taeku Lee; Secretary: Suzanne Mettler

Council Members: Michelle Deardorff, Maria Escobar-Lemmon, Roxanne Euben, Amaney Jamal, Frances Lee, Brett Ashley Leeds, David Lublin, Marc Lynch, James Mahoney, Byron D'Andra Orey, Bo Rothstein, Cameron Thies, Caroline Tolbert, and Mark Warren
\end{abstract}

APSA Staff: Kara Abramson, Regina Chavis, Patrick French, Dan Gibson, Meghan McConaughey, Kimberly Mealy, Teka Miller, Steven Rathgeb Smith, Betsy Super, and Barbara Walthall

Guests: Phillip Ardoin and Rodney E. Hero

Not in Attendance: Jeffrey Isaac, John Ishiyama, Kimberly Morgan, David Obey, Tasha Philpot, Deborah Schildkraut, and David Stasavage

\section{CALL TO ORDER}

APSA President Jennifer Hochschild called the meeting to order on August 31, 2016 at 8:30 a.m.

\section{CONSENT AGENDA}

Spring 2016 Council Meeting minutes and 2016-2017 committee appointments are introduced as part of the consent agenda. There are no questions or corrections to the minutes or the committee appointments. President Hochschild moves to approve the spring 2016 Council Meeting minutes, motion is seconded, and approved unanimously. Amaney Jamal moves to approve the committee appointments. The motion is seconded, and approved unanimously.

\section{TREASURER'S REPORT}

T. Lee introduces the treasurer's report to update the Council on the Association's financial position. T. Lee reports that APSA is in sound financial shape. The Association has $\$ 33.43$ million in investments; $\$ 14.52$ million in the trust and development portfolio,
\$15.04 million in the Congressional Fellowship Program trust portfolio, and is projecting revenue of $\$ 7.7$ million from operations. T. Lee notes that APSA has entered contingent litigation with the firm who installed their HVAC system. He updates them on the cost and timeline of this litigation. Hochschild ask for a motion to approve the treasurer's report, the motion is made, seconded, and approved unanimously.

\section{PRESIDENT'S REPORT}

President Hochschild introduces the president's report to update the Council on current issues facing the Association. Hochschild discusses recent issues that may pose challenges for the Association and provides updates on journal transitions as well as the anti-harassment statement and process. She also highlights the large portions of the discipline that are in non-tenured roles, and how the Council can better serve these members. T. Lee, Ardoin, and Lublin discuss how they believe the Association could work to incorporate those in non-tenure track positions. Euben voices her concern with alienation by subfield and how this affects everyone. She believes a committee should be created to study these trends and advise Council on how they can best work. Euben and Mettler express what specific aspects they would like for the proposed committee to study.

\section{ANNUAL MEETING FORMAT}

Smith introduces a presentation on meeting attendance and format, focusing on innovative panel types. This discussion is meant to update the council on the uptake and interest in innovative panel formats and solicit Council feedback on the annual meeting format for coming years. Hochschild and Smith explain the rationale for various changes and new additions to this year's Annual Meeting. Hochschild also explains the changes in participation rules that the Council had previously reviewed. These rules were intended to promote innovation in the Annual Meeting, and to increase the number and diversity of participants. Hochschild opens the floor for discussion. Amaney, Smith, and McConaughey discuss the trends in paper acceptance rates. Smith does not believe we will be able to determine trends in paper acceptance rates until next year. Rothstein suggests the Annual Meeting Committee propose some new ideas to for panel formats. Tolbert would like to implement a trial period for innovative formats. Orey expresses support for the iPoster format. Baumgartner argues that innovations will take some time to catch on. Mahoney references other associations that take advantage of the "conference within a conference" format and he suggests that this could serve the association well. Lake believes innovation is beneficial, and he would like to see some concrete proposals from the Meeting and Conference Committee in April.

\section{EXECUTIVE DIRECTOR'S REPORT}

Smith provides an update on APSA's journals, section journal contracts, strategic plan updates, building maintenance, Council handbook, and governance reform. Tolbert voices her concerns with ensuring that any custom conference software remains functional and up-to-date. F. Lee expressed agreement that custom software systems for large organizations must be carefully considered.

\section{GOVERNANCE REFORM}

Lake introduces the discussion of governance reform for the purpose of confirming Council support for the proposed bylaw amendments and determining the council position on an expected amendment from the floor. Lake refreshes Council on the work of the Ad Hoc Committee on Governance Reform to revise the bylaws, and the various drafts that the Council has seen. Lake reminds the Council that the most recent draft has been open to the public all summer and that the Council has a final chance to propose changes before they are considered at the All-Member Business Meeting. Lake notes that an amendment to section I.3.D is expected from the floor from APSA member J. Stoner, and Council should have a position on this expected amendment. Lake opens the floor for discussion. Lynch, T. Lee, Hero and Euben discuss their concern with section I.3.D that discusses issues of public policy.Jamal asks for clarification of what has changed between the old and the new bylaws and Hero, Lublin, and Warren offer clarification. Hochschild and Mettler discuss the implications of the proposed amendment limiting statements on public policy by inserting 
the phrase "the Association may not otherwise commit its members on matters of public policy" into section I.3.D. T. Lee suggests a friendly amendment to instead use the wording "the Association may not otherwise commit itself." Lynch suggests contacting Stoner to suggest T. Lee's friendly amendment. Lublin suggests setting time limits in the debates, and Hochschild informs him of the plan to do so. Senior Director of Research and Development Betsy Super offers clarification on the procedure for adding this language. Smith informs everyone that Stoner accepts the language as an improvement to his original amendment. Hochschild makes a motion for the Council to endorse Stoner's proposed amendment to section I.3.D with T.Lee’s edit, thus reading “... but the Association may not otherwise commit itself on matters of public policy." Motion is seconded, and approved.

\section{MEMBERSHIP REPORT}

Smith introduces Director of Membership Teka Miller to discuss membership trends, goals for membership growth and retention, as well as planned changes in membership categories and income levels for Council approval. Miller outlines new initiatives to increase membership. Hochschild asks for comments to the plan. Warren and Jamal suggest areas for growth and Miller informs them projects related to these issues are in progress. Escobar-Lemmon believes that APSA should be more transparent about the value of a membership. Rothstein suggests ways to encourage non-academic political scientists to become members. Leeds provides some suggestions for Miller's next report. EscobarLemmon believes that most members do not understand the benefits they get, and suggests communications emphasizing member benefits. Finnemore asks if the Association thinks it would be worth exploring APSA for undergraduates, and Miller agrees. Hochschild draws attention to the changes in membership categories and income levels which require a Councilvote. Motion to change "high school teacher category" to "K-12 educator" made, seconded, and approved; motion to move community college faculty from the associate member category to the professional member category made, seconded, and approved; motion to add "under \$30,0oo" and "\$30,ooo\$39,999" income categories made, seconded, and approved. The final motion to increase membership rates for income categories over $\$ 50,000$ is made and seconded. Leeds asks how this price point is determined and Miller explains. Hochschild asks Super about individuals reporting cost as being too high in the previous member survey and Super explains. The motion passes unanimously.

\section{ETHICS COMMITTEE/}

\section{ANTI-HARASSMENT POLICY}

Super introduces an update and discussion on the work of the ethics committee in developing an anti-harassment policy for APSA events and meetings, for the purpose of providing an interim report to the Council. Super provides background on the current state of the work the ethics committee has done addressing sexual harassment at the meeting. Hochschild asks what would happen under this policy if someone were accused of sexual harassment at the Annual Meeting. Super reported that a response to a situation like this would be up to Council as there is no existing hearing process. Jamal suggests that we should be mimicking how other associations handle circumstances such as these. Jamal, Hochschild, and Leeds discuss APSA's liability. Several Council members indicate that deciding on a clear procedure for this circumstance is urgent. Lake moves to charge the membership and professional development policy committee with developing procedures for dealing with harassment accusations for consideration by the Council at the April Council meeting. T. Lee suggests amending the motion to move the timeframe earlier to ensure that a policy is in place for the 2017 Annual Meeting. Super, Thies, Baumgartner, and Tolbert discuss the legal issues behind developing procedures to deal with harassment accusations. Hochschild reiterates the current motion: to charge the membership and professional development committee to develop a specific proposal which will go to the Executive Committee in time for the Executive Committee to vet it, to then be revised as necessary and be disseminated prior to the April Council meeting for a Council vote at the April Council meeting. This motion is seconded. Lynch moves to amend this motion, striking "membership and professional development committee" and substituting "ad hoc committee of current Council members to be constituted by the Executive Director in consultation with the President." The amendment is seconded and passes unanimously. The amended motion passes unanimously.

\section{PERSPECTIVES ON POLITICS} EDITOR SEARCH

Lynch introduces discussion of the search committee's recommendation for a new editorial team for Perspectives on Politics for Council consideration and approval. Lynch begins with background on the extensive work done by the editorial search committee and explains the goals of the proposed editorial team. Lynch expresses that the editorial team would like to keep most of the current editorial board. Hero, Lynch, and Thies discuss the rationale for keeping the editorial board. Lublin and Lake make suggestions to encourage innovation. Hochschild reminds Council that they also approve the editorial board, separately from the editorial team. Jamal asks why the editorial oversight issues that have come up have not had ongoing Council engagement. Smith agrees and believes the new publications policy committee will help with this. Lake believes this is part of a larger conversation in regards to the position of the journal editors in APSA. Tolbert asks about the plan for the editorial board, and Hochschild explains. Lublin makes a motion to approve the editorial team with the expectation that they will replace $50 \%$ of the board in the near future, the motion is seconded. Euben and Ardoin discuss the motion. Hochschild restates Lublin's motion, and asks for votes. Euben and Lublin discuss edits to motion. Lublin withdraws his first motion and moves to approve a four-year term for the recommended editorial team while encouraging substantial rotation of the editorial board. The motion is seconded and approved.

\section{OPEN ACCESS JOURNAL}

Smith introduces discussion on the search for an editorial team for the APSA open access journal for the purpose of updating the Council on this process. Smith gives background on the call for proposals for the open access journal, the proposals received, and the committee's thoughts about the proposal. The proposed editorial team was given comments and a deadline to resubmit the new proposal. Warren asks what could be done to attract more people to this journal, Tolbert suggests a stipend. Hochschild, Smith, and Tolbert discuss the finances of the Open Access Journal. Smith believes that the issue with journals is that they are a time consuming job and can take individuals away from their own personal work. Hochschild discusses the possibility of hiring someone full time to work on the journal, and the issues that may arise in doing this. Council will revisit this issue in April after the search committee has reviewed the updated proposal.

\section{DAVID LAKE TASK FORCE}

Lake introduces discussion of his presidential task force for the purpose of soliciting advice from the Council. Lake gives an update on the development of his task force and his 
current thinking. At this point he believes it would be inappropriate to develop the task force focusing on research transparency and will instead delay action on this until the Qualitative Transparency Deliberations decision in early 2017. Instead, Lake will constitute two committees on research ethics, one on conflict of interest policies and one on human subjects research. Tolbert and F. Lee offer suggestions for potential focus and committee members.

\section{THELEN TASK FORCE}

Thelen introduces discussion of her planned presidential task force for approval by Council. Thelen refers the Council to her proposal and discusses planned members of the task force. She plans for the task force to be a two step process in which data will be collected and analyzed, and from those results proposals will be developed and implemented. She then asks for comments. Leeds expresses concern that the task force list is not sufficiently diverse. Thelen explains her rationale for selecting these members. Leeds believes the data collection is the most crucial part of this process and most dependent on diversity. Jamal, Mettler, and Thelen discuss issues of diversity on the task force. Hochschild reminds the Council that this is a vote on the current roster of the committee. Tolbert suggests some changes to increase institutional diversity. Jamal moves to approve the structure of the task force as specified in Thelen's task force proposal, but with strong encouragement for increasing diversity in the membership of the task force. The motion is seconded and approved unanimously.

\section{AWARDS POLICY}

Smith introduces discussion of the proposed update to the APSA award policy for Council consideration and approval. Smith and Super explain the award policy's purpose, when it was last updated, and what the newly proposed awards policy would do. Baumgartner suggests that an award does not always necessarily need to come with monetary compensation. Lublin agrees and thinks the focus should be on the award and not the prize. Super clarifies that the proposal under consideration would recommend continuation of the current process for creating new awards, requiring a reasonable funding plan for all new awards, a regular review of award names, creation of recommendations for new awards starting in FY 2018, and review of the awards policy in approximately five years. Smith suggests that there should also be provisions for cowinners or honorable mention and that recommendations for this provision be brought to the Council at a later date. Motion is made to accept all current recommendations. Euben moves to amend recommendation two to read: "New awards are required to have a reasonable funding plan (including the possibility of no financial component for an award) and this will be shared with the new award committee at the time of the award creation." Motion is seconded, and approved unanimously.

\section{GIFT POLICY}

Super introduces discussion of the proposed policy on accepting gifts for Council consideration and approval. Super explains the work done with a consultant to develop a policy regarding the gifts that ASPA can receive because APSA did not previously have a formal policy on this issue. Warren asks if there is anything in the policy that prohibits the donor from steering any APSA projects. Super and Smith discuss the proposal, and Super suggests revising the proposal to include what Warren is suggesting. Hochschild made another suggestion for text to be added. The proposed policy will be updated and will later be presented for a Council vote via e-mail.

\section{NEW SECTION}

Smith introduces discussion of the proposal for a new section on American Political Thought that has been submitted for Council approval. He provides background on the new section and the process the section has gone through before coming before Council. Hochschild and Finnemore discuss specifics of section proposal. Tolbert and Lynch inquire about the role of the Council in the process of approving the new section. Hochschild, Smith, and Leeds discuss the larger role of the Council in section governance. Rothstein moves to table the proposal until the issue of section governance is further considered. Motion is seconded, and fails. Motion to approve proposal for new section made, seconded, and approved.

Lake moves to create an ad hoc committee on policies regarding the creation of new sections and review of current sections. The motion is seconded and approved unanimously.

\section{CAMBRIDGE CONTRACT}

Smith introduces discussion of the proposed contract renewing Cambridge University Press as publisher of APSA journals, for the purpose of Council approval. Smith gives background on Cambridge and the history of APSA's relationship with the publisher. The contract is up for renewal and APSA has been involved in extensive talks with the publisher to revise the document. Smith explains the provisions of the 10-year contract. Motion is made to approve the contract. Motion is seconded and approved unanimously.

\section{TEACHING AND LEARNING CONFERENCE DISCUSSION}

Smith introduces discussion of the 2017 Teaching and Learning Conference for the purpose of updating the Council on current siting issues. Smith gives background on the current situation affecting the conference site, and details how he plans to keep Council updated as new information comes to him.

\section{BUDGET}

Chavis gives background on the budget and explains to the Council that the document in front of them is lacking the most up-todate figures due to the timing of the finalized Cambridge contract. Hochschild asks for a motion to approve the budget. The motion is seconded and approved.

\section{NEW BUSINESS}

Super introduces discussion of a new committee to oversee the creation of a second Kenneth Sherrill Award for predissertation work to study LGBT politics for the purpose of approval by the Council. Lublin moves to approve the committee. The motion is seconded, and approved unanimously. 